\title{
STRATEGI PEMASARAN UNTUK MENINGKATKAN JUMLAH KUNJUNGAN WISATAWAN DI BANDA ACEH
}

\author{
${ }^{1}$ Yuslaidar Yusuf, ${ }^{2}$ Huzairin Fandefi \\ ${ }^{1,2}$ Universitas Muhammadiyah Aceh \\ yuslaidar.yusuf@unmuha.ac.id
}

\begin{abstract}
ABSTRAK
Menganalisis strategi pemasaran untuk meningkatkan jumlah kunjungan wisatawan di Banda Aceh. Maka dengan ini di butuhkan seseuatu formula yang tepat. Berdasarkan latar belakang masalah dan keterbatasan waktu, biaya, tenaga dan ilmu penelitian maka penelitian ini difokuskan pada strategi pemasaran untuk meningkatkan jumlah kunjungan wisatawan di Banda Aceh. Jenis penelitian ini yaitu penelitian deskriptif yang merupakan jenis penelitian yang menggambarkan apa yang dilakukan oleh pemerintah Kota Banda Aceh berdasarkan fakta-fakta yang ada untuk selanjutnya diolah menjadi data. Hasil penelitian menunjukkan bahwa faktor-Faktor yang mempengaruhi Kota Banda Aceh adalah Faktor internal pemasaran Kota Banda Aceh adalah dari segi strengths (kekuatan) meliputi objek wisata di Kota Banda Aceh mudah dijangkau dari bandara dan dari Kota Banda Aceh, fasilitas dan pelayanan penginapan dan perhotelan yang baik. Dari segi weaknesses (kelemahan) meliputi kurangnya pemandu wisata yang menguasai bahasa asing, sebagian tempat wisata belum memiliki toilet, kurangnya kualitas pelayanan transfortasi umum (Transkuraja). Faktor eksternal pada pemasaran Kota Banda Aceh adalah dari segi opportunities (peluang) meliputi mempromosi sebagai salah Destinasi wisata halal, dapat pemanfaatan teknologi untuk memberikan informasi wisata ke luar Kota Banda Aceh. Dari segi threat (ancaman) meliputi tempat wisata di daerah lainnya yang menjadi pesaing, potensi bencana alam yang dapat mengganggu dan menghambat jasa transfortasi dan lainnya dan meningkatnya minat masyarakat untuk melakukan perjalanan wisata ke daerah lainnya. Strategi pemasaran yang diterapkan saat ini oleh Kota Banda Aceh adalah strategi bauran pemasaran meliputi lokasi atau tempat wisata dan penyediaan fasilitas, promosi yang dilakukan cara sosialiasi dan promosi di berbagai media.
\end{abstract}

Kata Kunci: Strategi pemasaran, Kunjungan wisatawan, Promosi 


\section{PENDAHULUAN}

Membangun sektor pariwisata perlu dilakukan melalui pentahapan menurut suatu kerangka waktu tertentu. Harus diakui, selama lima tahun lalu, pengembangan sektor pariwisata sudah mulai membuahkan hasil, meskipun masih terdapat kekurangan namun pencapaian-pencapaian dimasa lalu sebenarnya sudah berada pada jalur yang benar. Konsep Trilogi Pembangunan yang terdiri dari pertumbuhan ekonomi, stabilitas politik dan pemerataan pendapatan antar berbagai kelompok dalam masyarakat merupakan penompang utama bagi pengembangan sektor-sektor lain.

Dalam pemasaran terdapat strategi pemasaran yang disebut bauran pemasaran (marketing mix) yang memiliki peranan penting dalam mempengaruhi konsumen agar dapat membeli suatu produk atau jasa yang ditawarkan oleh perusahaan. Elemen-elemen bauran pemasaran terdiri dari semua variabel yang dapat dikontrol perusahaan untuk dapat memuaskan para konsumen. Marketing mix merupakan strategi mencampur kegiatankegiatan marketing, agar dicari kombinasi maksimal sehingga mendapatkan hasil yang paling memuaskan (Ginting, 2016). sebuah perusahaan. Untuk mengetahui jumlah wisatawan Nusantara di Banda Aceh dapat dilihat pada tabel I.1 berikut ini:

\section{Tabel I.1}

\section{Data Wisatawan Nusantara di Banda Aceh dari tahun 2013 s/d 2017}

\begin{tabular}{|c|c|c|c|c|}
\hline \multirow{2}{*}{ No } & Tahun & \multicolumn{2}{|c|}{ Jumlah Wisatawan } & \multirow{2}{*}{ Jumlah } \\
\cline { 3 - 4 } & & Nusantara & Mancanegara & \\
\hline 1 & 2013 & 256.526 & 7.257 & 263.783 \\
\hline 2 & 2014 & 229.575 & 11.164 & 240.739 \\
\hline 3 & 2015 & 267.880 & 13.398 & 281.278 \\
\hline 4 & 2016 & 268.103 & 18.527 & 286.630 \\
\hline 5 & 2017 & 272.194 & 28.714 & 300.908 \\
\hline
\end{tabular}

Sumber : BPS Nasional, (2018) (https://www.bps.go.id)

Berdasarkan tabel di atas dapat dijelaskan bahwa jumlah wisatawan Nusantara di Banda Aceh dari tahun 2013 sampai tahun 2017 mengalami peningkatan dan penurunan atau fluktuasi. Hal ini dapat diketahui bahwa pada tahun 2013 jumlah wisatawan Nusantara di Banda Aceh sebanyak 256.526 orang. Kemudian pada tahun 2014 jumlah wisatawan Nusantara di Banda Aceh sebanyak 229.575 orang. Pada tahun 2015 jumlah wisatawan Nusantara di Banda Aceh sebanyak 267.880 orang. Pada tahun 2016 jumlah wisatawan Nusantara di Banda Aceh sebanyak 268.103 dan tahun 2017 jumlah

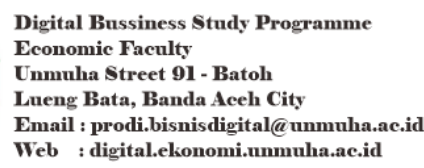


wisatawan Nusantara di Banda Aceh 272.194 orang. Kemudian dari tabel 1.1 di atas dapat diketahui bahwa jumlah wisatawan Mancanegara di Banda Aceh dari tahun 2013 sampai tahun 2017 mengalami peningkatan. Hal ini dapat diketahui bahwa pada 2013 jumlah wisatawan Mancanegara di Banda Aceh sebanyak 7.257 orang. Jumlah wisatawan Mancanegara di Banda Aceh pada 2014 sebanyak 11.164 orang. Jumlah wisatawan Mancanegara di Banda Aceh pada tahun 2015 sebanyak 13.398 orang. Kemudian pada tahun 2016 jumlah wisatawan Mancanegara di Banda Aceh sebanyak 18.527 dan jumlah wisatawan Mancanegara di Banda Aceh pada 2017 sebanyak 28.714 orang.

Rendahnya kunjungan wisatawan di objek-objek wisata di Kota Banda Aceh, disebabkan oleh promosi yang dilakukan oleh pihak pemerintah Kota Banda Aceh masih rendah. Promosi yang dilakukan oleh pemerintah Kota Banda Aceh seperti pada saat ada kunjungan Walikota keluar daerah maupun keluar negeri. Hal ini dapat diketahui melalui beberapa media yaitu koran, majalan dan Televisi seperti melaui koran yaitu pada 21 Maret 2018 "Banda Aceh promosi wisata di Bandara Kualanamu”, dan pada 9 April 2018 "Wali Kota Banda Aceh promosi wisata di Jepang". Kemudian promosi tempat wisata yang dilakukan oleh pemerintah Kota Banda Aceh dilakukan pada saat acara tertentu saja seperti pameran, Pekan Kebudayan Aceh, acara ulang tahun Kota Banda Aceh dan berbagai kegiatan yang dilakukan oleh Dinas Kebudayaan dan Pariwisata Kota Banda Aceh. Oleh karena itu perlu dikembangkan suatu model pemasaran objek dan daya tarik wisata serta fasilitas wisata sebagai upaya untuk meningkatkan jumlah kunjungan wisatawan.

Faktor-Faktor yang mempengaruhi Kota Banda Aceh adalah Faktor internal pemasaran Kota Banda Aceh adalah dari segi strengths (kekuatan) meliputi objek wisata di Kota Banda Aceh mudah dijangkau dari bandara dan dari Kota Banda Aceh, fasilitas dan pelayanan penginapan dan perhotelan yang baik, harga tiket masuk objek wisata terjangkau dan pasca konflik dan tsunami, Aceh menjadi salah satu tujuan wisata yang di incar wisatawan nusantara maupun wisatawan mancanegara. Dari segi weaknesses (kelemahan) meliputi kurangnya pemandu wisata yang menguasai bahasa asing, sebagian tempat wisata belum memiliki toilet, kurangnya kualitas pelayanan transfortasi umum (Transkuraja) dan sejumlah tempat wisata lahan parkirnya tidak memadai.

Faktor eksternal pada pemasaran Kota Banda Aceh adalah dari segi opportunities (peluang) meliputi dapat mempromosi sebagai salah satu Destinasi wisata halal, dapat 
memanfaatan teknologi untuk memberikan informasi wisata ke luar Kota Banda Aceh dan adanya kebijakan dari pemerintah daerah untuk mengembangkan pariwisata. Dari segi threat (ancaman) meliputi terdapat tempat wisata di daerah lainnya yang menjadi pesaing, potensi bencana alam yang dapat mengganggu dan menghambat jasa transfortasi dan lainnya dan meningkatnya minat masyarakat untuk melakukan perjalanan wisata ke daerah lainnya.

Strategi pemasaran tempat wisata yang diterapkan saat ini oleh Kota Banda Aceh adalah strategi bauran pemasaran meliputi promosi, promosi yang dilakukan oleh pemerintah Kota Banda Aceh seperti mempromosikan berbagai tempat wisata atau kuliner melalui Bandara, pemerintah Kota Banda Aceh juga memanfaatkan kesempatan untuk mempromosikan tempat wisata pada saat pertemuan dengan pemerintah daerah atau negara lain, kemudian mengadakan berbagai kegiatan seperti pameran, Pekan Kebudayaan Aceh dan lainnya. Kemudian pemerintah Kota Banda Aceh juga memanfaatkan berbagai teknologi untuk mempromosikan Kota Banda Aceh.

Berdasarkan fenomena diatas maka penulis tertarik melakukan penelitian dengan judul : Strategi Pemasaran Untuk Meningkatkan Jumlah Kunjungan Wisatawan Di Banda Aceh.

\section{TEORI}

Aktivitas pemasaran sangat penting artinya untuk mencapai tujuan perusahaan, karena aktivitas pemasaran diarahkan untuk mengetahui dan memahami kebutuhan dan keinginan pelanggan sehingga produk dan jasa yang ditawarkan itu cocok serta menentukan dan memilih pasar sasaran dan menciptakan pertukaran yang memungkinkan perusahaan mencapai laba yang diharapkan. Adapun pengertian pemasaran menurut para ahli dikemukakan sebagai berikut.

Pemasaran menurut Gitosudarmo (2015:1) dapat diartikan sebagai suatu kegiatan yang mengusahakan agar produk yang dipasarkannya itu dapat diterima dan disenangi oleh pasar. Pemasaran bertujuan untuk memberikan kepuasan terhadap keinginan dan kebutuhan pengonsumsi serta mendatangkan keuntungan bagi pihak perusahaan. Pemasaran merupakan bidang manajemen yang sangat berperan dalam usaha mencapai tujuan perusahaan yaitu keuntungan dari penjualan, sehingga kelangsungan kegiatan perusahaan dapat bertahan dan berkembang. 
Manajemen pemasaran yang efektif biasanya mencakup perencanaan, strategi dari seluruh usaha organisasi. Manajemen pemasaran dapat terjadi disebuah organisasi dalam hubungan dengan pasarnya dan juga untuk mempengaruhi tingkat, jangkauan, waktu dan komposisi permintaan dalam suatu cara sehingga membentuk organisasi untuk mencapai sasarannya.

Menurut Kotler dan Armstrong (2014:146) pengertian manajemen pemasaran adalah sebagai berikut: Manajemen Pemasaran adalah penganalisaan, pelaksanaan, dan pengawasan, program-program yang ditujukan utuk mengadakan pertukaran dengan pasar yang dituju dengan maksud untuk mencapai tujuan organisasi. Hal ini sangat tergantung pada penawaran organisasi dalam memenuhi kebutuhan dan keinginan pasar tersebut serta menentukan harga, mengadakan komunikasi, dan distribusi yang efektif untuk memberitahu, mendorong serta melayani pasar.

\section{Strategi Pemasaran}

Strategi pemasaran adalah rencana yang menjabarkan ekspektasi perusahaan akan dampak dari berbagai aktivitas atau program pemasaran terhadap permintaan produk atau lini produknya di pasar sasaran tertentu. Perusahaan bisa menggunakan dua atau lebih program pemasaran secara bersamaan, sebab setiap jenis program seperti periklanan, promosi penjualan, personal selling, layanan pelanggan, atau pengembangan produk memiliki pengaruh yang berbeda-beda terhadap permintaan. Oleh sebab itu, dibutuhkan strategi yang dapat mengkoordinasikan program-program pemasaran agar programprogram itu sejalan dan terintegrasi dengan sinergistik. Mekanisme ini disebut sebagai strategi pemasaran. Umumnya peluang pemasaran terbaik diperoleh dari upaya memperluas permintaan primer, sedangkan peluang pertumbuhan terbaik berasal dari upaya memperluas permintaan selektif. (Kotler and Amstrong, 2014:193)

Menurut Rangkuti (2014:3), strategi adalah alat untuk mencapai tujuan. Tujuan utamanya adalah agar perusahaan dapat melihat secara obyektif kondisi-kondisi internal dan eksternal, sehingga perusahaan dapat mengantisipasi perubahan lingkungan eksternal. Dalam hal ini dapat dibedakan secara jelas fungsi manajemen, konsumen, distributor, dan pesaing. Jadi, perencanaan strategis penting untuk memperoleh keunggulan bersaing dan memiliki produk yang sesuai dengan keinginan konsumen 
dengan dukungan yang optimal dari sumber daya yang ada. Untuk memahami konsep perencanaan strategis, kita perlu memahami pengertian konsep mengenai strategi.

\section{Jenis-Jenis Strategi Pemasaran}

Suatu aspek yang paling penting dalam melaksanakan segmentasi pasar adalah aspek operasional. Hal ini berarti ahwa kita harus menghindarkan diri dari dimensi yang tidak dapat dilaksanakan. Dasar segmentasi yang dipakai haruslah dapat dilaksanakan. Dasar pelaksanaan segmentasi umumnya dipergunakan segmentasi atas dasar demografis (kependudukan) seperti umur, jenis kelamin, penghasilan daerah, penghasilan keluarga dan sebagainya. Informasi kependudukan semacam itu sangat mudah memperolehnya dan sangat berguna dalam hal promosi dan distribusi. Setelah diketahui bahwa pasar yang dihadapi dapat dibagi-bagi ke dalam strategi yang mungkin dilakukan terhadap keadaan tersebut.

Assauri (2015:163) bahwa strategi pemasaran secara umum ini, dapat dibedakan tiga jenis strategi pemasaran yang dapat ditempuh perusahaan yaitu :

1. Strategi pemasaran yang tidak membeda-bedakan pasar (Undifferentiated marketing).

2. Strategi pemasaran yang membeda-bedakan pasar (Differentiated marketing).

3. Strategi pemasaran yang terkonsentrasi (Concentrated Marketing).

\section{Analisis SWOT}

Setiap unit bisnis harus dievaluasi kekuatan dan kelemahannya secara periodik. Analisis ini memberikan kesimpulan bahwa meskipun suatu bisnis memiliki kekuatan yang tinggi pada faktor tertentu, kekuatan ini tidak langsung merupakan keunggulan bersaing. Pertama, barangkali kompetensi itu tidak begitu penting bagi para pelanggan di pasar. Kedua, meskipun kompetensi diperlukan, mungkin saja para pesaing lain memiliki kekuatan sederajat. Oleh karena itu, yang paling penting bagi suatu unit bisnis adalah memiliki kekuatan yang relatif lebih besar untuk faktor mikro dibandingkan dengan para pesaingnya.

SWOT adalah singkatan dari kata-kata Strength (kekuatan perusahaan) Weaknesses (kelemahan perusahaan), Opportunities (peluang bisnis) dan Threats (hambatan untuk mencapai tujuan). Menurut Tjiptono (2014:8) Analisis SWOT adalah analisis yang terdiri dari analisis lingkungan mikro yang bertujuan untuk mengetahui 
kekuatan dan kelemahan perusahaan, dan analisis lingkungan makro yang bertujuan untuk mengetahui peluang dan ancaman bagi perusahaan.” Menurut Kotler (2014:88) mengemukakan bahwa : "analisis SWOT adalah evaluasi terhadap keseluruhan kekuatan, kelemahan, peluang dan ancaman."

Selanjutnya Rangkuti (2014:19) mengemukakan bahwa : "analisis SWOT membandingkan antara faktor eksternal peluang (opportunities) dan ancaman (threats) dengan faktor internal kekuatan (strenghts) dan kelemahan (weaknesses)." Analisis SWOT dapat diterapkan dengan cara menganalisis dan memilah berbagai hal yang mempengaruhi ke-empat faktor SWOT. Kemudian menerapkan dalam gambar matriks SWOT. Aplikasinya adalah bagaimana kekuatan mampu mengambil keuntungan dari peluang yang ada, bagaimana cara mengatasi kelemahan yang mencegah keuntungan dari peluang yang ada, bagaimana kekuatan mampu menghadapi ancaman yang ada, dan bagaimana cara mengatasi kelemahan yang mampu membuat ancaman menjadi nyata atau menciptakan ancaman baru.

Manajemen unit bisnis sekarang perlu mengetahui informasi tentang lingkungan yang harus dipantau dan dipahami jika unit bisnisnya ingin mencapai sasaran yang telah ditetapkan. Secara umum, perusahaan harus memantau variabel-variabel lingkungan mikro yang signifikan dan yang mempengaruhi kemampuan perusahaan dalam menghasilkan keuntungan di pasar tersebut. Juga harus dipantau kekuatan-kekuatan lingkungan makro yang berpengaruh langsung maupun tidak langsung terhadap bisnisnya

Identifikasi SWOT sangat penting karena langkah-langkah berikutnya dalam proses perencanaan untuk pencapaian tujuan yang dipilih mungkin diturunkan dari SWOT. Pembuat keputusan harus menentukan apakah tujuan dapat dicapai berdasarkan faktor-faktor SWOT. Jika tujuannya tidak dapat dicapai, tujuan yang berbeda harus dipilih dan proses berulang. Cara lain untuk memanfaatkan SWOT adalah Matching and Converting. Matching digunakan untuk mencari keunggulan kompetitif dengan cara mencocokkan kekuatan terhadap kesempatan. Konversi (converting) adalah menerapkan strategi konversi untuk mengubah kelemahan menjadi kekuatan atau ancaman menjadi peluang. Contoh dari strategi konversi adalah mencari pasar baru. Jika ancaman atau kelemahan tidak dapat dikonversi, maka perusahaan harus mencoba untuk memperkecil atau menghindari ancaman/kelemahan itu. 
Analisis SWOT adalah satu pekerjaan yang cukup berat karena hanya dengan itu alternatif-alternatif stratejik dapat disusun. Kegagalan menganalisisnya berarti gagal dalam mencari relasi dan titik temu antara faktor-faktor stratejik dalam lingkungan internal dan yang terdapat dalam lingkungan eksternal, sambil mencari hubungannya dengan misi, tujuan, dan sasaran organisasi juga merupakan kegagalan dalam mempersiapkan suatu keputusan stratejik yang baik.

\section{METODE}

Desain penelitian merupakan rencana dan struktur penelitian yang dibuat sedemikian rupa untuk memperoleh jawaban atas pertanyaan-pertanyaan penelitian. Menurut Sekaran (2017:152) desain penelitian adalah rencana struktur penelitian yang mengarahkan proses dan hasil penelitian sedapat mungkin menjadi valid, objektif, efisien, dan efektif. Desain penelitian dapat meliputi beberapa elemen yaitu; tujuan penelitian, jenis penelitian, horizon waktu dan unit analisis.

Tujuan dalam penelitian ini untuk mengetahui fenomena atau permasalahan yang terjadi di Kota Banda Aceh. Lokasi penelitian adalah Dinas Kebudayaan dan Pariwisata Kota Banda Aceh. Obyek penelitian yang dipilih dalam penyusunan skripsi ini adalah strategi pemasaran dalam meningkatkan kunjungan wisata atau analisis strategi SWOT

Penelitian Deskriptif adalah jenis penelitian yang menggambarkan apa yang dilakukan oleh pemerintah Kota Banda Aceh berdasarkan fakta-fakta yang ada untuk selanjutnya diolah menjadi data. Data tersebut kemudian dianalisis untuk memperoleh suatu kesimpulan. Penelitian ini menggunakan metode kualitatif, dimana peneliti akan melakukan observasi langsung ke lapangan dan mengumpulkan data-data yang akan dianalisis berdasarkan pengamatan dan pengetahuan peneliti. Pengamatan atau observasi merupakan suatu unsur penting dalam penelitian kualitatif, observasi dalam konsep yang sederhana adalah sebuah proses atau kegiatan awal yang dilakukan oleh peneliti untuk bisa mengetahui kondisi, realitas lapangan penelitian. Observasi dalam penelitian kualitatif adalah pengamatan langsung terhadap objek untuk mengetahui keberadaan objek, situasi, konteks dan maknanya dalam upaya mengumpulkan data penelitian.

Dalam penelitian ini horizon waktu yang digunakan adalah one shot atau cross sectiaonal, yaitu horizon waktu yang mengumpulkan data penelitian hanya dalam sekali 
kumpul. Penelitian ini dimulai dari bulan Desember tahun 2018 hingga bulan Februari tahun 2019.

Unit analisis merujuk pada tingkat kesatuan data yang dikumpulkan selama tahap analisis data. Unit analisis Individual adalah data yang dikumpulkan dari setiap individu unit.Jika peneliti berminat mempelajari interaksi dua orang maka dikenal sebagai unit analisis pasangan (dyads). Sifat informasi yang dikumpulkan serta tingkat dimana data dijumlahkan untuk analisis, adalah integral dengan keputusan yang dibuat dalam memilih unit analisis. Peneliti memutuskan unit analisi bahkan saat kita merumuskan pertanyaan penelitian karena metode pengumpulan data ditentukan oleh tingkat dimana data dijumlahkan untuk analisis.

Sumber data merupakan sumber di mana data dapat diperoleh peneliti. Dalam memilih sumber data, peneliti harus benar-benar berfikir mengenai kemungkinan kelengkapan informasi yang akan dikumpulkan juga validitasnya. Menurut Sutopo (2014: 56), "Pemahaman mengenai berbagai macam sumber data merupakan bagian yang sangat penting bagi peneliti karena ketepatan memilih dan menentukan jenis sumber data akan menentukan ketepatan dan kekayaan data atau kedalaman informasi yang diperoleh".

Dalam penyusunan skripsi ini, penulis melakukan penelitian dengan cara sebagai berikut :

a. Observasi yaitu penelitian yang dilakukan dengan mengadakan pengamatan secara langsung pada Dinas Kebudayaan dan Pariwisata Kota Banda Aceh dalam proses kegiatan pengolahan data.

b. Wawancara yaitu teknik pengumpulan data yang dilakukan dengan mengadakan wawancara lansung dengan pimpinan Dinas Kebudayaan dan Pariwisata Kota Banda Aceh serta sejumlah karyawan yang memiliki keterkaitan langsung dengan permasalahan yang penulis kemukakan.

c. Dokumentasi yaitu pengumpulan data yang dilakukan dengan jalan mengumpulkan dokumen-dokumen yang ada kaitannya dengan masalah yang akan di bahas

\section{Teknik Analisis Data}

Teknik analisis data dalam penelitian ini yang digunakan pada penelitian ini adalah metode deskriptif. Menurut Sugiyono (2014:21) teknik deskriptif adalah metode yang digunakan untuk menggambarkan atau menganalisis suatu hasil penelitian tetapi 
tidak digunakan untuk membuat kesimpulan yang lebih luas. Alasan peneliti menggunakan metode penelitian deskriptif ini agar memudahkan peneliti untuk menjawab pertanyaan penelitian yang berkaitan dengan hubungan variabel dan juga mencari hubungan komparasi antar variabel.

Di dalam menganalisis data, metode yang digunakan adalah desktiriptif kualitatif dan kuantitatif dengan pendekatan manajemen strategi dan manajemen pemasaran selanjutnya disajikan dalam bentuk tabulasi, bagan dan uraian. Analisis deskriptif kualitatif digunakan untuk mengetahui lingkungan perusahaan yang menjadi kekuatan, kelemahan, peluang, dan ancaman yang dihadapi oleh Dinas Kebudayaan dan Pariwisata Kota Banda Aceh. Sedangkan analisis kuantitatif digunakan pada matrik SWOT.

Untuk menentukan posisi persaingan di dalam perusahaan digunakan metode Analisis SWOT yang membandingkan faktor internal (kekuatan dan kelemahan) dan faktor eksternal (peluang dan ancaman). Berikut skema dari analisis SWOT dapat dilihat pada gambar 3.1 dibawah ini:

Gambar 3. 1

Skema Matriks SWOT

\begin{tabular}{|c|c|c|}
\hline $\begin{array}{r}\text { FAKTOR } \\
\text { EAKTOR }\end{array}$ & $\begin{array}{r}\text { KEKUTATAN } \\
\text { PERUSAHAAN }\end{array}$ & $\begin{array}{c}\text { KELEMAHAN } \\
\text { PERUSAHAAN }\end{array}$ \\
\hline PELUANG BISNIS & STRATEGI S $-\mathrm{O}$ & STRATEGI $\mathrm{W}-\mathrm{O}$ \\
\hline ANCAMAN BISNIS & STRATEGI S $-\mathrm{T}$ & STRATEGI $\mathrm{W}-\mathrm{T}$ \\
\hline
\end{tabular}

Sumber : Irham (2014: 224)

a. Strategi SO

Dirumuskan dengan pertimbangan bahwa manajemen hendak memanfaatkan kekuatan perusahaan dan keunggulan bersaing yang dimiliki untuk mengeksploitasi peluang bisnis yang tersedia. 
b. Strategi WO

Diperoleh ketika manajemen mencoba memanfaatkan peluang perusahaan yang tersedia untuk mengurangi bahkan mengeliminasi kelemahan perusahaan yang ada.

c. Strategi ST

Serupa dengan strategi WO karena kedua variabel yang ada tidak maksimal. Stategi ST lahir dari analisis manajemen yang hendak menggunakan kekuatan dan keunggulan yang dimiliki menghindari efek negatif dari ancaman perusahaan yang di hadapi.

d. Strategi WT

Pada dasarnya lebih merupakan strategi bertahan yakni strategi perusahaan yang masih mungkin ditemukan dan dipilih dengan meminimalisasi kelemahan dan menghindari ancaman bisnis.

\section{DISKUSI DAN HASIL}

\section{Strategi Pemasaran Kota Banda Aceh}

Setiap Dinas Kebudayaan dan Pariwisata pasti mempunyai strategi dalam meningkatkan jumlah wisatawan atau pengunjung pada wilayahnya masing-masing. Rata-rata setiap Dinas Kebudayaan dan Pariwisata menggunakan strategi pemasaran dengan tujuan memperkenalkan tempat wisata tersebut kepada masyarakat. Strategi yang dilakukan oleh Kota Banda Aceh adalah sebagai berikut :

a. Promosi

Tujuan dalam melakukan promosi adalah untuk memperkenalkan Kota Banda Aceh harus meningkatkan sistem promosi agar masyarakat dapat mengetahui apa saja wisata yang ada di Kota Banda Aceh sehingga masyarakat dapat menambah wawasan masyarakat,

b. Harga

Penentuan harga sangat penting bagi Kota Banda Aceh agar tidak terjadinya kerugian bagi Kota Banda Aceh maupun wisatawan. Penetapan harga harus di atas harga fasilitas, pelayanan dan lain-lain yang telah dikeluarkan oleh Kota Banda Aceh. Kemudian dalam penetapan harga juga harus sesuai dengan harga pasar (harga pesaing) agar wisatawan dapat melakukan pertimbangan dari faktor yang lainnya 
untuk melakukan Kota Banda Aceh tertentu. Penentuan harga yang terlalu tinggi dapat menyebabkan wisatawan berkurang, karena setiap wisatawan akan melakukan perbandingan seperti harga pemasaran, harga paket wisata, harga fasilitas yang digunakan, harga jasa yang ditetapkan oleh pertempat wisataan kepada wisatawan dan harga lainnya yang berhubungan dengan para wisatawan di Kota Banda Aceh

c. Produk

Produk merupakan hal yang sangat penting dalam strategi pemasaran. Kota Banda Aceh harus meningkatkan pelayanan dan fasilitas agar jumlah kunjungan wisatawannya semakin meningkat. Pelayanan dan fasilitas yang disediakan oleh pihak pemerintah Kota Banda Aceh harus benar-benar baik agar wisatawan tetap percaya dalam melakukan kunjungan wisata. Wisatawan akan memilih tempat wisata yang memiliki kelebihan tersendiri atau keunggulan dari tempat wisata yang lainnya dengan yang disediakan oleh pihak pemerintah Kota Banda Aceh

d. Tempat

Salah satu pertimbangan pada saat akan membuka tempat wisata adalah lokasi wisata. Dalam memilih lokasi atau tempat wisata harus kita pertimbangkan dengan matang karena tempat wisata yang tidak tepat dan tidak strategis akan membuat tempat wisata tidak berjalan seperti harapan. Kesalahan dalam memilih lokasi wisata dapat menyebabkan jumlah kunjungan wisatawan yang tidak sesuai dengan yang diharapkan karena kurang dari jangkauan wisatawan atau akan berdampak kurang baik dan sebaliknya ketepatan dalam menentukan lokasi wisata strategis akan berdampak positif bagi kemajuan tempat wisata.

e. Pelayanan

Pelayanan yang baik dan ramah terhadap wisatawan salah satu faktor memberikan kepuasan bagi wisatawan. Pemerintah Kota Banda Aceh harus melayani wisatawan dengan ramah kepada wisatawan pada saat wisatawan melakukan kunjungan di Kota Banda Aceh. Pihak Kota Banda Aceh harus menjaga kenyamanan atau keamanan terhadap wisatawan.

\section{Analisis Perkembangan Jumlah Kunjungan Wisatawan}

Dalam pembahasan mengenai strategi pemasaran, maka terlebih dahulu dilakukan evaluasi mengenai perkembangan jumlah kunjungan wisatawan yang bertujuan untuk 
mengetahui seberapa besar perubahan naik atau turunnya jumlah kunjungan wisatawan yang dicapai oleh Kota Banda Aceh. Namun sebelum dilakukan analisis perkembangan jumlah kunjungan wisatawan pada Kota Banda Aceh, terlebih dahulu akan disajikan data jumlah kunjungan wisatawan pada Kota Banda Aceh dari tahun 2008 s/d 2017 yang diperoleh dari Kota Banda Aceh yaitu sebagai berikut:

\section{Tabel IV.3}

Data jumlah kunjungan wisatawan Kota Banda Aceh tahun 2008 s/d 2017

\begin{tabular}{|c|c|c|r|}
\hline No & Tahun & $\begin{array}{c}\text { Jumlah jumlah } \\
\text { kunjungan } \\
\text { wisatawan }\end{array}$ & $\begin{array}{c}\text { Perkembangan } \\
(\boldsymbol{\%})\end{array}$ \\
\hline 1 & 2008 & 9.155 & $-42,29 \%$ \\
\hline 2 & 2009 & 5.283 & $-26,76 \%$ \\
\hline 3 & 2010 & 3.869 & $3,39 \%$, \\
\hline 4 & 2011 & 4.000 & $7,178 \%$ \\
\hline 5 & 2012 & 4.287 & $69,28 \%$ \\
\hline 6 & 2013 & 7.257 & $53,83 \%$ \\
\hline 7 & 2014 & 11.164 & $20,01 \%$ \\
\hline 8 & 2015 & 13.398 & $38,28 \%$ \\
\hline 9 & 2006 & 18.527 & $54,98 \%$ \\
\hline 10 & 2017 & 28.714 & \\
\hline
\end{tabular}

Sumber : BPS Kota Banda Aceh, 2019

Berdasarkan tabel di atas dapat dijelaskan bahwa perkembangan jumlah kunjungan wisatawan di Kota Banda Aceh mengalami fluktuasi. Pada tahun 2010 menurun sebesar 26,76\%. Pada tahun 2011 meningkat sebesar 3,38\%, tahun 2012 meningkat sebesar 7,17\% dan pada tahun 2013 meningkat sebesar 69,27\%. Kemudian perkembangan jumlah kunjungan wisatawan di Kota Banda Aceh pada tahun 2014 meningkat sebesar 53,83\%, pada tahun 2015 jumlah kunjungan wisatawan meningkat sebesar 20,01\%. Perkembangan jumlah kunjungan wisatawan di Kota Banda Aceh pada tahun 2016 meningkat sebesar 38,28\% dan jumlah kunjungan wisatawan pada tahun 2017 sebesar $54,98 \%$ 


\section{PENUTUP}

\section{Kesimpulan}

Dari hasil analisis dan pembahsan yang telah dikemukakan pada Bab sebelumnya, maka penulis dapat menarik beberapa kesimpulan yaitu:

1. Faktor yang mempengaruhi Kota Banda Aceh adalah Faktor internal pemasaran Kota Banda Aceh adalah segi strengths (kekuatan) meliputi objek wisata di kota Banda Aceh mudah di jangkau dari bandara dan dari kota Banda Aceh, fasilitas dan pelayananpenginapandan perhotelan yang baaik, harga tiket masuk objek wisata terjangkau. Dari segi weaknesses (kelemahan) meliputi kurangnya pemandu wisata yang menguasai bahasa asing, sebagai tempat wisata belum memiliki toilet, kurangnya kualitas pelayanan transfor umum (transkutaraja) dan sejumlah tempat wisata lahan parkir tidak memadai.

2. Faktor eksternal pada pemasaran Kota Banda Aceh adalahdari segi opportunities (peluang) meliputi promosi sebagai Destinasi wisata halal, dapat memanfaatkan teknologi untuk memberikan informasi wisata halal, memanfaatkan teknologi untuk memberikan informasi wisata ke luar Kota banda Aceh.

3. Strategi pemasaran yang diterapkan saat ini oleh Kota Banda Aceh adalah strategi bauran pemasaran meliputi lokasi atau tempat wisata dan menyediakan fasilitas, promosi yang dilakukan cara sosialisasi dan promosi di berbagai media.

\section{Saran}

Dari hasil analisis serta hasil kesimpulan yang dilakukan oleh penulis, maka saransaran yang diberikan terkait dengan strategi pemasaran Kota Banda Aceh adalah sebagai berikut:

1. Meningkatkan fasilitas wisata khususnya di wilayah Kota Banda Aceh seperti wisata kuliner dan wisata Alam.

2. Meningkatkan pelayanan kepada wisatawan serta menyediakan bergagai fasilitas yang memadai.

3. Dapat meningkatkan berbagai kegiatan promosi yang dapat menarik perhatian kepada wisatawan. 


\section{DAFTAR PUSTAKA}

Alma, Buchari. (2014). Manajemen Pemasaran dan Pemasaran Jasa, Bandung: Alfabeta Assauri Sofjan. (2015). Manajemen Pemasaran, edisi kesatu, cetakan kesembilan, Raja Grafindo Persada, Jakarta

Ginting, Nurlaila. (2016). Strategi Pemasaran Untuk Meningkatkan Jumlah Kunjungan Wisata DKI Jakarta. Jurnal Analisis Ekonomi Utama Volume X, Nomor 2.

Gitosudarmo, Indriyo. (2015). Manajemen Pemasaran, edisi kedua, cetakan keenam, Penerbit : BPFE - Yogyakarta

Ketler dan Armstrong. (2014). Manajemen Pemasaran. Jakarta. Erlangga Ketler dan Armstrong. (2014). Manajemen Pemasaran. Jakarta. Erlangga

Kotler, P. dan Keller, K. (2014). Manajemen Pemasaran. Jakarta: Erlangga.

Kotler, Philip. (2014) Manajemen Pemasaran, edisi keduabelas, cetakan pertama, Jilid I dan II, terjemahan Hendra Teguh, PT. Erlangga, Jakarta.

Rangkuti, Fredy. (2014). Analisis SWOT Teknik Membedah Kasus Bisnis, cetakan kelima Belas tujuh, Penerbit : Gramedia Pustaka Utama, Jakarta.

Sugiyono. (2014). Statistika Untuk Penelitian Bisnis, Bandung: Alfabeta Suparno, Indra. (2015). Implementasi Strategi Pemasaran Wisata Keraton Kasepuhan Dalam Membangun Daya Tarik Wisata Kota Cirebon. Skripsi Kementerian Agama Republik Indonesia Institut Agama Islam Negeri (IAIN) Syekh Nurjati Cirebon 